Bond University

Research Repository

\title{
Financial-distress prediction of Islamic banks using tree-based stochastic techniques
}

Halteh, Khaled; Kumar, Kuldeep; Gepp, Adrian

Published in:

Managerial Finance

DOI:

10.1108/MF-12-2016-0372

Licence:

CC BY-NC

Link to output in Bond University research repository.

Recommended citation(APA):

Halteh, K., Kumar, K., \& Gepp, A. (2018). Financial-distress prediction of Islamic banks using tree-based stochastic techniques. Managerial Finance, 44(6), 759-773. https://doi.org/10.1108/MF-12-2016-0372

\footnotetext{
General rights

Copyright and moral rights for the publications made accessible in the public portal are retained by the authors and/or other copyright owners and it is a condition of accessing publications that users recognise and abide by the legal requirements associated with these rights.
}

For more information, or if you believe that this document breaches copyright, please contact the Bond University research repository coordinator. 


\title{
FINANCIAL-DISTRESS PREDICTION OF ISLAMIC BANKS USING TREE-BASED STOCHASTIC TECHNIQUES
}

\begin{abstract}
Financial distress is a socially and economically important problem that affects companies the world over. Having the power to better understand - and hence aid banks from failing, has the potential to save not only the bank, but potentially prevent economies from sustained downturn. Although Islamic banks constitute a fraction of total banking assets, their importance has been substantially increasing, as their asset growth rate has surpassed that of conventional banks in recent years. This paper uses a data-set comprising 101 international publicly-listed Islamic banks to work on advancing financial distress prediction by utilising cutting-edge stochastic models, namely: decision trees, stochastic gradient boosting, and random forests. The most important variables pertaining to forecasting corporate failure are determined from an initial set of 18 variables. Our results indicate that the "Working Capital/Total Assets" ratio is the most crucial variable relating to forecasting financial distress using both the traditional 'Altman Z-Score' and the 'Altman Z-Score for Service Firms' methods. However, using the 'Standardised Profits' method, the "Return on Revenue" ratio was found to be the most important variable. This provides empirical evidence to support the recommendations made by Basel Accords for assessing a bank's capital risks, specifically in relation to the application to Islamic banking. These findings provide a valuable addition to the limited literature surrounding Islamic banking in general, and financial distress prediction pertaining to Islamic banking in particular, by showcasing the most pertinent variables in forecasting financial distress so that appropriate proactive actions can be taken.
\end{abstract}

Keywords - bankruptcy prediction; financial distress; variable importance; tree-based stochastic models; Islamic banking

\section{Introduction}

Islamic banks dominate the market share in predominantly Muslim nations, especially in the Middle East region with $80 \%$ market share vis-à-vis $20 \%$ in the rest of the world. Their presence has also expanded on a global scale and they can be found in more than 50 countries (Hanif, 2011). Figure 1 below shows the banking penetration and participation asset market share for Islamic banks. The graph clearly shows that the countries with the highest market share of Islamic banks are Middle Eastern nations with predominantly Muslim population, while banking penetration is higher amongst nations with a greater number of conventional banks. 


\section{Figure 1: Banking Penetration and Participation Asset Market Share}

\section{Banking penetration and Participation asset market share}

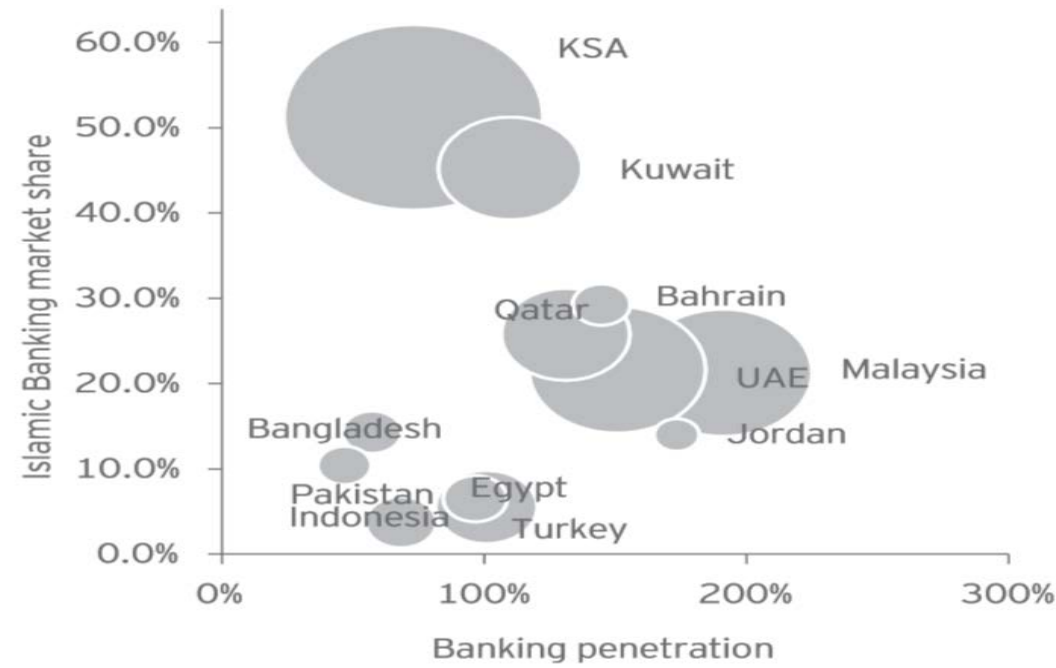

Size of circle $=$ Islamic Banking Assets

Source: $(E Y, 2016)$

Shariah-compliant financial assets are predicted to reach \$3 trillion in the next decade - an increase from approximately $\$ 2$ trillion in the year 2016, as well as sales of Islamic bonds, called sukuk, increased by 24\% to \$44 billion in 2016 (Liau, 2017). According to Standard \& Poor's (2014), Islamic banking asset-growth has been overtaking conventional banks for a number of years - as shown in Figure 2 below. This demonstrates the importance for expanding the currently limited literature available on Islamic banks, and even more so, financial distress prediction pertaining to Islamic banks.

\section{Figure 2: Asset Growth Comparison: Islamic and Conventional Banks}

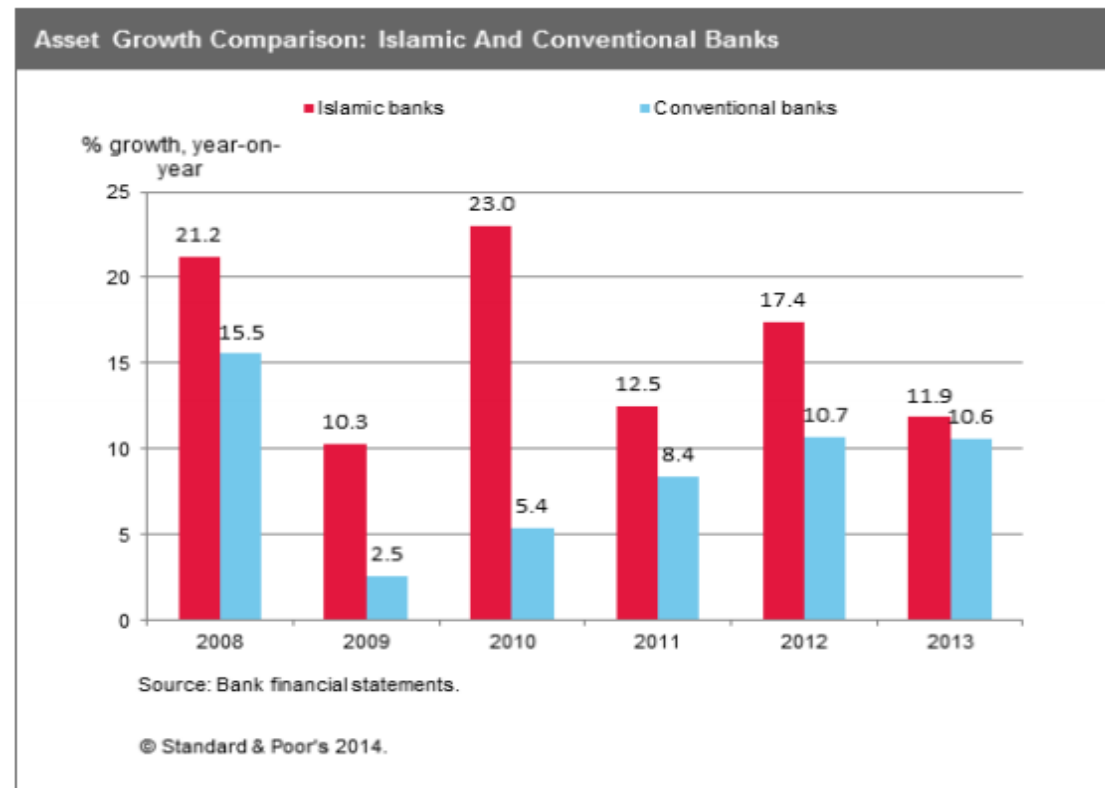

Source: (Standard \& Poor's, 2014) 
Financial Distress Prediction (FDP) involves predicting financial difficulties of an organisation before it happens. It is known by many names, including: Bankruptcy Failure Prediction, Corporate Failure, Financial Insolvency, Financial Risk, and Credit Default to name a few. For consistency purposes, Financial Distress Prediction will be used to refer to the aforementioned synonyms, and will be often referred to by its acronym FDP. There are many causes that lead to financial distress - the leading causes can be classified according to financial, economic, neglect, disaster, or fraud aspects (Anderson, 2006). This paper will primarily focus on the financial aspect by using financial ratios as inputs into distress prediction models.

Financial risks are crucial indicators of a bank's standing as they put further successful operation of the bank under threat. Their influence leads to a decrease in financial performance and a weakened financial position, with the potential to eventually lead to bankruptcy. This would have an adverse effect on not only the bank, but its stakeholders as well - many of whom are members of the public. That is, the very fabric of society might get affected, especially if it was a large bank. This effect is even more magnified when it pertains to Islamic banks, as its users are religiously restricted to operating with conventional banks, thus their choices are limited. Failure of an Islamic bank might even cause a big blow to the very feasibility of Islamic banking, which might lead to dire consequences amongst its patrons.

FDP includes developing statistical models that predict the financial failure or success of a company based on publicly available information, such as financial ratios from financial statements (Gepp \& Kumar, 2012). These models can then be used by the company itself and various institutions to aid in developing proactive and preventive decisions, in order to avoid impending financial distress. This early warning signal of financial distress could help management take pre-emptive actions to prevent potential insolvency, hence reducing tangible incurred losses (Jaikengit, 2004). Therefore, the accuracy of predicting companies' financial distress is an increasingly important issue in accounting, finance, statistics, and other company fields (Cybinski, 2001; Yu et al., 2014). Researchers on the topic have utilized a variety of statistical models - discriminant analysis, logistic regression, and decision trees to name a few, in order to find the best financial distress prediction tool.

FDP has many advantages, including: allowing banks to assess a person's/firm's financial distress probability before determining whether a loan is suitable, and if so, how much excess and premium to charge - in the case of Islamic banks, a murabaha contract, where the bank purchases a good then on-sells it to the buyer at a premium price (Beck et al., 2013). Governments and watchdog institutions can also utilize the models to focus on banks with high financial distress probabilities. Lastly, other stakeholders and potential merger companies can assess the likelihood of a bank's failure or success as an indicator of whether there will be sustainable benefits gained from continuous operation with the bank at hand (Gepp \& Kumar, 2012). If you wish to use this manuscript for commercial purposes, please contact permissions@emerald.com. 
The following sections explore the literature surrounding the topic, then moves on to the data section, followed by the methodologies adopted in this study. The results are then presented and discussed before an overall conclusion.

\section{Literature Review}

Despite there being a large number of papers that use statistical models to deal with financial distress prediction, only a fraction of those deal with the banking industry, and of those a handful pertain to Islamic banking. The papers vary in the way the techniques used, but their core aim is the same: to get the most accurate models possible. Table 1 - found at the end of the Literature Review section - provides a comparison of the accuracy of various FDP models used in prior studies. The table was developed from reviewing in excess of 100 papers from the field of FDP and manually classifying them according to the statistical technique(s) used. In the literature, Type I Error refers to misclassifying a failing business as successful, whereas Type II Error refers to misclassifying a successful business as a failing one, both are costly errors to make (Gepp \& Kumar, 2012). The same error definitions are used below.

The prediction of financial distress for financial businesses has been extensively researched ever since the early 1930s, pioneered by Fitzpatrick (1932). This research was furthered by Beaver (1966) through establishing the first modern statistical model - the Univariate Model, which used individual financial ratios for FDP. He tested this model on 158 businesses, half of which were successful and the other half were failed. His model's error rate was approximately 22\% for Type I Error and 5\% for Type II Error. However, this was not timeconstant. The error rate increased as the length of prediction increased, which is problematic for long-term predictions. Another issue faced by Beaver's model was that different ratios could result in conflicting predictions, that is, will cease to be a feasible model (Gepp \& Kumar, 2012).

Following Beaver's univariate analysis, the first multivariate model applied to FDP was discriminant analysis (Altman, 1968). It aimed at tackling the main problem faced by Beaver's models, that being potential conflicting predictions. He devised a single weighted score (Z) for each business based on five variables, which was calculated according to the following equation:

$$
\mathrm{Z}=\mathbf{1 . 2 \times 1}+\mathbf{1 . 4 \times 2}+3.3 \times 3+0.6 \times 4+1.0 \times 5 \quad \mathrm{Xi}=\text { independent variables }
$$

x1: working capital / total assets

x2: retained earnings / total assets

x3: earnings before interest and tax / total assets

x4: market value of equity / total liabilities

$\mathbf{x} 5$ : total revenue/total assets 
Multivariate Discriminant Analysis (MDA) has been used in many business financial distress prediction studies, including: Chung et al. (2008); Lee \& Choi (2013); Altman et al. (2014). MDA is one of the most popular models in the literature for analysing corporate financial distress (Perez, 2006). The chief benefit of MDA for predicting business financial distress is its capability to reduce a multidimensional problem to a single score with a fairly high level of accuracy.

Altman (1968) used financial ratios as the independent variables because cash flow ratios were found to be statistically insignificant, a contrast to Beaver's findings. Based on the results, cut-off scores were then generated to classify each business, as shown in Figure 3. Altman's model outperformed that of Beaver's; however, the time issues persisted, that is, longer predictions were noticeably less accurate (Gepp \& Kumar, 2012). The short-term accuracy of the model was $95 \%$, however, that drops down to $72 \%$ when it is for two or more years prior to bankruptcy Altman (1968).

\section{Figure 3: Classification using Altman's Z-score Model}
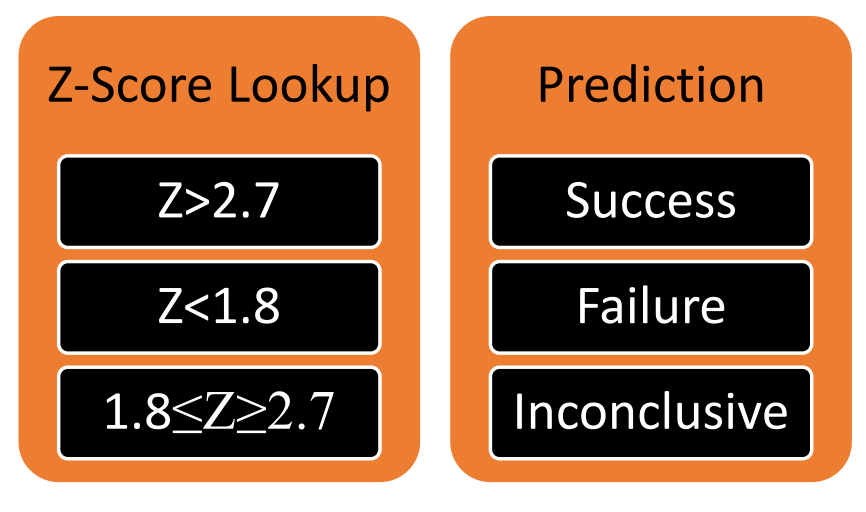

Ohlson (1980) carried out research into the probabilistic prediction of businesses' financial distress using Logistic Regression (LR). Similar to Altman's Z-score, Ohlson's O-score is a statistical financial distress indicator produced from a predefined set of financial statements ratios. LR has been used in many business financial distress prediction studies, e.g.: Laitinen \& Laitinen (2001); Hua et al. (2007); Chen (2011); Daniel \& Ionut (2013). LR has the benefit over MDA of being less affected when basic statistical assumptions, such as the multivariate normality of the variables are violated; though, similar to discriminant analysis, its predictive power remains time-constrained (Altman, 1993). According to Ohlson (1980), logistic regression requires four main steps, namely:

(1) Identify a number of financial ratios;

(2) Fit a logistic regression model and deduce the ratios' coefficients;

(3) Calculate the result of each coefficient to establish a new fitted dependent variable ' $y$ ';

(4) Calculate the probability of financial distress for a company as $1 /\left(1+e^{-y}\right)$.

Here, the independent variables with a positive coefficient increase the probability of financial distress due to the fact that they reduce e ${ }^{y}$ towards zero, resulting in the financial 
distress (probability function) approaching 1 or $100 \%$. Similarly, the independent variables with a negative coefficient decrease the probability of financial distress.

A non-parametric technique that has been used for FDP is Artificial Neural Networks (ANNs), such as by: Tan (2001); Coats \& Fant (1993); Lee \& Choi (2013); Ciampi \& Gordini (2013). ANNs are computer systems that consist of algorithms which can be trained to mimic the inner workings of the human brain (Hertz et al., 1991). It is made up of interconnected units that process and evaluate the interactions between the units in a complex set of existing data. ANNs assign weights to the respective inputs to enable the precise deduction of the ultimate outcome (Dorsey et al., 1995). One drawback however, is that the learning stage of ANNs can be long and cumbersome. This is less of an issue with today's increased computing power, but there are still a large number of decisions for the expert designer to make in the training process. This is why there has been research into computing methods to optimise the training of ANNs.

Recursive partitioning is the name for a set of non-parametric techniques for multivariate analysis. They evolved to remove the distribution assumptions associated with parametric models, such as discriminant analysis and logistic regression (Breiman, 1984) and provide a useful alternative to the parametric regression models (Zhang \& Singer, 2010). On the other hand, recursive partitioning does not provide accurate probabilities associated with a failure or success prediction. They can provide an estimate for a whole node, but this is rarely accurate. Furthermore, a formal hypothesis test for assessing the significance of variables does not yet exist (Altman, 1993). Examples of recursive partitioning techniques include: decision trees, stochastic gradient boosting, and random forests. Although the prior literature on using these techniques is limited, the results have been very encouraging and consequently, they will be the focus of this paper.

Decision Trees (DT) are models that construct a set of tree-based classification rules that incrementally break down a dataset into smaller subsets. DTs have not been as extensively used in financial distress prediction studies vis-à-vis their parametric counterparts. Some of the studies that adopt DTs for FDP include: Chen (2011), Hung \& Chen (2009), and Gepp et al. (2010). According to Gepp et al. (2010), decision trees are found to be superior predictors vis-à-vis MDA when it pertains to forecasting business financial distress; this claim is solidified by various studies: Chen (2011); Frydman et al. (1985); Kumar \& Ravi (2007); Geng et al. (2015); Huarng et al. (2005); Sun \& Li (2008). Various DT building algorithms may be used to create decision trees. Even though similar tree structures are generated by all building algorithms, the choice of which algorithm to utilize can have a significant influence on the accuracy of the final outcome. Prior research has used both Classification And Regression Trees (CART) and See5 models. Research by Gepp et al. (2010) and Huarng et al. (2005) has shown that CART is empirically superior to See5.

Random Forests (RF) is an ensemble model for regression and classification that creates many DTs. In classification, the output is the category that was predicted by the most individual trees (the mode). In a regression context, the output is the average from all If you wish to use this manuscript for commercial purposes, please contact permissions@emerald.com. 
individual trees. There are only a handful of studies that deal with business financial distress prediction using random forests, e.g.: Fantazzini \& Figini (2009); Nanni \& Lumini (2009); Chandra et al. (2009).

Stochastic Gradient Boosting (SGB) is also an ensemble technique, but in contrast go RF, it generates thousands of small decision trees constructed in a sequential error-correcting method to aggregate to an accurate model. There are only a handful of studies that deal with business financial distress prediction using SGB, including: Kumar \& Ravi (2007); Ravi et al. (2007); Mukkamala et al. (2006). These studies showed that SGB outperformed its counterpart statistical intelligent models, including individual decision trees.

The advantages of both random forests and stochastic gradient boosting over individual trees is that they are much more stable with references to changes in the data.

Table 1: Percentage Comparison of Different FDP Models Use in the Literature

\begin{tabular}{|c|c|}
\hline Model & $\begin{array}{c}\text { Percentage found in } \\
\text { literature }\end{array}$ \\
\hline MDA & $27 \%$ \\
\hline LR & $25 \%$ \\
\hline ANN & $29 \%$ \\
\hline DT & $7 \%$ \\
\hline RF & $5 \%$ \\
\hline SGB & $5 \%$ \\
\hline Other & $2 \%$ \\
\hline
\end{tabular}

\section{Data}

This research extracted financial data for the year 2014 using a data-set of 101 Islamic banks that operate on a global scale. The number of independent variables used is 18 - comprising financial ratios, actual figures, margins, and rates, as shown in Table 2 below. The variables were chosen based upon several factors, including: standard accounting and financial variables that adopt data from the respective bank's financial statements, variables used in prior empirical research, and as per availability of data.

The data for the companies used in the research were extracted from the CapitalIQ database, that is, readily available archival data. According to Shultz et al. (2005), using archival data is advantageous since it is readily available, circumvents data collection woes, and contains much bigger samples, hence can perform innovative and more powerful statistical tests. CapitalIQ provides web-based information services that combine information on companies worldwide along with a variety of software applications that allow financial professionals to analyse company fundamentals, build financial models, screen for investment ideas, and 
execute other financial research tasks. Capital IQ has been extensively used throughout the literature (Phillips, 2012).

Table 2: Variables used in this study

\begin{tabular}{|l|l|}
\hline Variable & Description \\
\hline 1. Total Assets (TA) & Actual Balance Sheet Figure \\
\hline 2. Dividends/Shares & The number of dividends that the shareholders receive on a per-share basis \\
\hline 3. ROE (Return on Equity) & Net Income/ (shareholders' equity - outside equity interests) \\
\hline 4. ROA (Return on Assets) & Earnings before interest / (total assets less outside equity interests) \\
\hline 5. Operating Income/TA & Financial Ratio \\
\hline 6. Working Capital/TA & Financial Ratio \\
\hline 7. Retained Earnings/TA & Financial Ratio \\
\hline $\begin{array}{l}\text { 8. Earnings Before Income \& } \\
\text { Tax (EBIT)/TA }\end{array}$ & Financial Ratio \\
\hline $\begin{array}{l}\text { 9. Market Value of Equity/Total } \\
\text { Liabilities (MVE/TL) }\end{array}$ & Financial Ratio \\
\hline 10. Revenue/TA & Financial Ratio \\
\hline 11. Debt Ratio & Total Liabilities/Total Assets \\
\hline 12. Current Ratio & Current Assets/Current Liabilities \\
\hline 13. ROR (Return on Revenue) & Net Income/Total Revenue \\
\hline 14. Asset Turnover & Total Revenue/Total Assets \\
\hline 15. Efficiency Ratio & Total Expenses/Total Revenue \\
\hline 16. Total Equity/Total Assets & Financial Ratio \\
\hline 17. Equity Ratio & Total Equity/Total Assets \\
\hline 18. Total Debt/Total Equity & Financial Ratio \\
\hline
\end{tabular}

\section{Methodology}

\section{Methods of Financial Distress}

Three methods, Altman Z-Score, Altman Z-Score for Service Firms, and the Standardised Profits, were used to measure each bank's financial distress. All three were used as dependent variables and results compared and contrasted to increase the reliability of our results in this new area.

The independent variables are based on data for the year 2014, whereas the dependent variables (for all three methods), use 2015 data. That is, one-year lagged independent variables have been used. This allows for development of a model that can predict the financial state of Islamic banks one year in advance, so that there is time to take appropriate action if required. This may have implications for proactive measurements taken by various stakeholders, including shareholders and government bodies, as well as regulatory influences, such as the Basel Accords. These implications will be discussed in detail in the Discussion section. 
First, the 'Altman's (1968) Z-Score' method has been chosen because of its extensive use in the FDP literature. Five ratios were used to achieve a Z-score for each bank using data from the year 2015; the 5 ratios used were outlined in the 'literature review' section in the paper. However, the results for each Islamic bank were not classified as per Altman's (1968) classification, as we have conducted a regression analysis, not a classification/logistic binary analysis.

Secondly, 'Altman Z-Score for Service Firms' method (Jan \& Marimuthu, 2015) was used. This method was chosen since we are dealing with Islamic banks - a service industry, and so this approach is arguable more appropriate and accurate. This method has been applied by various researchers to the banking industries in a number of countries worldwide, including Greece, India, and Kenya, and they have achieved high FDP accuracy rates (Kyriazopoulos Georgios, 2014; Sharma et al., 2013; Mamo, 2010). Four ratios were used to achieve a Zscore for each bank using data for the year 2015 - the formula and ratios used are outlined below.

$$
\mathrm{Z}=6.856 \times 1+3.26 \times 2+6.72 \times 3+1.05 \times 4
$$

$\mathbf{X i}=$ independent variables

$\mathbf{x 1}$ : working capital / total assets

x2: retained earnings / total assets

x3: earnings before interest and tax / total assets

x4: market value of equity / total liabilities

Thirdly, the 'Standardized Profits' method (Beck et al., 2013) was used. This method was chosen as it is a novel approach that can be applied to FDP of banks, both conventional and Islamic. The standardised ' $z$ ' score is a measure of bank stability, which includes accounting measures of profitability, volatility, and leverage. Beck et al.'s (2013) results indicate that although Islamic banks are less efficient, they have higher intermediation ratios, asset quality and are better capitalised, which led them to outperform conventional banks during the GFC. Two ratios were used to achieve a standardised (z) score for each bank - the formula and ratios are presented below.

$$
\mathbf{z}=(\mathbf{R O A}+\mathbf{C A R}) / \mathrm{SD}(\mathbf{R O A})
$$

z: Indicates the distance from insolvency, combining accounting measures of profitability, leverage, and volatility.

SD: Standard Deviation of ROA

ROA (Return On Assets): Profits/Total Assets

CAR (Capital Asset Ratio): Total Equity/Total Assets

\section{Model Building: Recursive Partitioning Techniques}

The software package 'Salford Systems Modeler 8.0' was used to develop and test the recursive partitioning models. This software has been previously used in the literature (Gepp \& Kumar, 2012; Gepp et al., 2010). The statistical techniques that are used in the study are: 
decision trees, stochastic gradient boosting, and random forests. These models have been adopted as research presented in various studies have shown that recursive partitioning outperformed traditional models, such as MDA and logistic regression (Gepp \& Kumar, 2012; , Gepp et al., 2010; Kumar \& Ravi, 2007; Berg, 2007). Additionally, they have shown good empirical results and they don't make any distributional assumptions, which is a prudent thing in this case since not a lot is known about the area of Islamic banking. The techniques used and the way they were developed will be further explained in the following subsections.

The dependent variable changed based on the method we are using, i.e. Altman Z-Score, Altman Z-Score for Service Firms, or the Standardised Profits method. For each of the methods of financial distress, and using the 18 variables each time, we have used the following techniques to build a model in each case, namely: decision trees, random forests, and stochastic gradient boosting, to determine which of the independent variables provided the most 'predictive power' pertaining to FDP of Islamic Banks.

\section{Decision Trees (DT)}

As shown in Figure 4, DTs consist of the following:

- A root node: Topmost decision node that corresponds to the best predictor;

- Non-leaf nodes that project 2 branches leading to 2 distinct nodes;

- Leaf nodes: Represent a classification or decision - which in this case will be a level of financial distress;

- Connecting branches.

Figure 4: Decision Tree

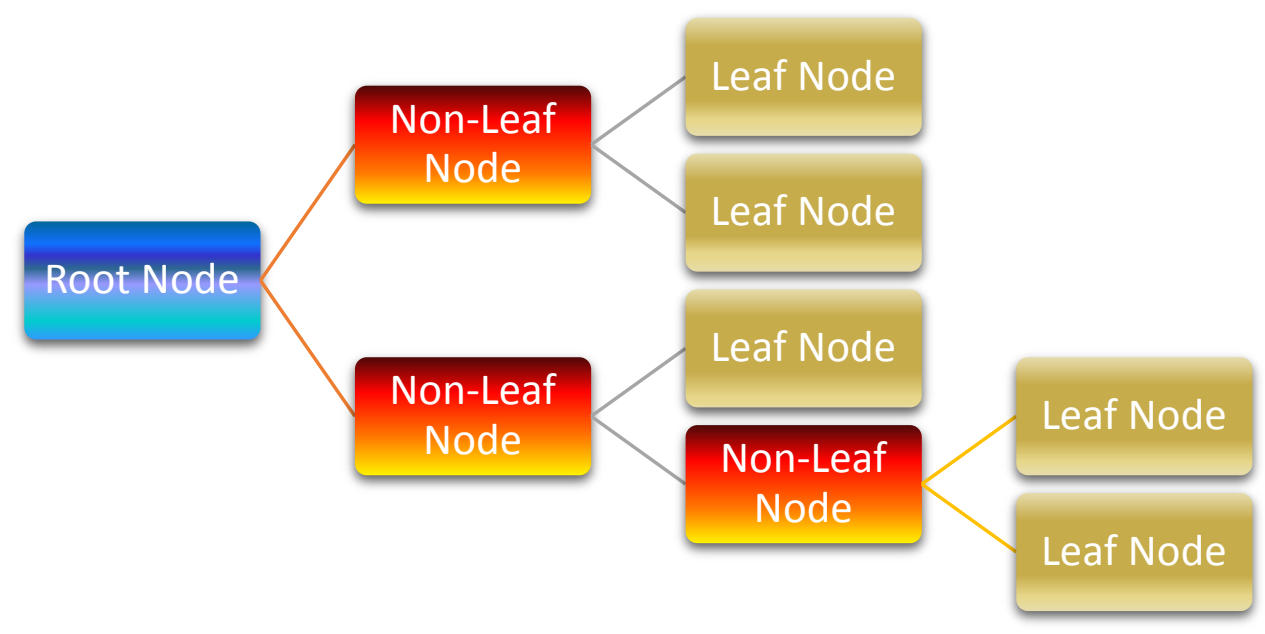

DTs allocate input objects to a leaf node. When testing for FDP, DTs assign companies in each leaf node a level of financial distress. Non-leaf nodes each contain a splitting rule. Hence, the tree is constructed by a recursive process of splitting the data from a higher level of the tree to a lower one. The splitting rule at each node defines the particulars of the split. 
The splitting rules contain a single variable that is contrasted to a cut-off value. According to Gepp \& Kumar (2012), there are 2 main tasks a DT building algorithm performs, namely:

1 Choosing the best splitting rule at each non-leaf node that distinguishes between financial distress of banks, and

2 Managing the complexity of the DT.

In this research, regression trees have been used with the standard Gini criterion to determine the best splitting rule at each point. All 18 variables were used as predictors (independent variables), and the target variable (dependent variable) was selected as one of Altman ZScore, Altman Z-Score for service firms, or the Standardised Profits method, to achieve results for all three models. The standard V-fold cross validation using 10 folds was used for the testing component of the model. This helps to ensure that the model is not over-trained, which means it detects patterns that appear in the data set given, but will not generalise well to new data.

\section{Random Forests (RF)}

As part of their structure, RF models lead to a dissimilarity measure between the observations. RF is advantageous for a number of reasons, including: handling mixed variables effectively, invariance to monotonic transformations of input variables, robustness to outlying observations, and accommodation to different strategies for dealing with missing data. RF effortlessly deals with numerous variables due to its intrinsic variable selection (Chandra et al., 2009). The same variables were used as for DTs. 20\% of cases were selected at random for the testing component of the model. Different numbers of trees were tested (200,500, and 1000) as out-of-bag data, which is again used for testing and avoiding overtraining to increase the generalisability of the findings, but500 trees were determined to be sufficient.

\section{Stochastic Gradient Boosting (SGB)}

SGB is a powerful and flexible data mining tool, capable of generating extremely accurate models. SGB's robustness includes data polluted with inaccurate target labels. This means that if the measures of financial distress aren't exactly accurate, then this technique is partially robust to that and is therefore a good technique for ranking variables. This sort of data error is generally difficult to deal with using traditional data analysis methods and is disastrous for conventional boosting. On the contrary, SGB is usually more immune to these errors. Additionally, SGB has a degree of accuracy that is typically not achievable by a single model or ensembles like bagging or conventional boosting (Mukkamala et al., 2006). The standard V-fold cross validation using 10 folds was used for the testing component of the model. Different numbers of trees were tested, but for similar reasons as stated previously, 200 stochastic random boosting trees were finally determined to be sufficient. 


\section{Results}

The models for each of the three definitions of financial distress are analysed separately below. Table 3, at the end of this section, provides a summary of the most important variables in each model, according to both technique and definition of financial distress. A sample DT will be shown for each method. For RF and SGB, a similar visualisation is unattainable because they are an ensemble of many trees, which is one of their disadvantages, but they are likely to be more accurate and good at handling inaccuracies in the data.

\section{Altman Z-Score Method}

Using a single decision tree with 'Working Capital/Total Assets' as the root node, the most important variable, followed by ROA as the next non-leaf node, leading through connecting branches to multiple consecutive non-leaf nodes and finally ending with leaf nodes. See Figure 5 for an illustration. The ratio of Working Capital to Total Assets was also the most important variable in both the RF and SGB models. Current Ratio appeared as the second most important variable using decision tree and RF, whereas the Debt Ratio was the second most important variable using SGB. Refer to Table 3 for more detail. 
Figure 5: Decision Tree Model using Altman’s Z-Score as the measure of Financial Distress

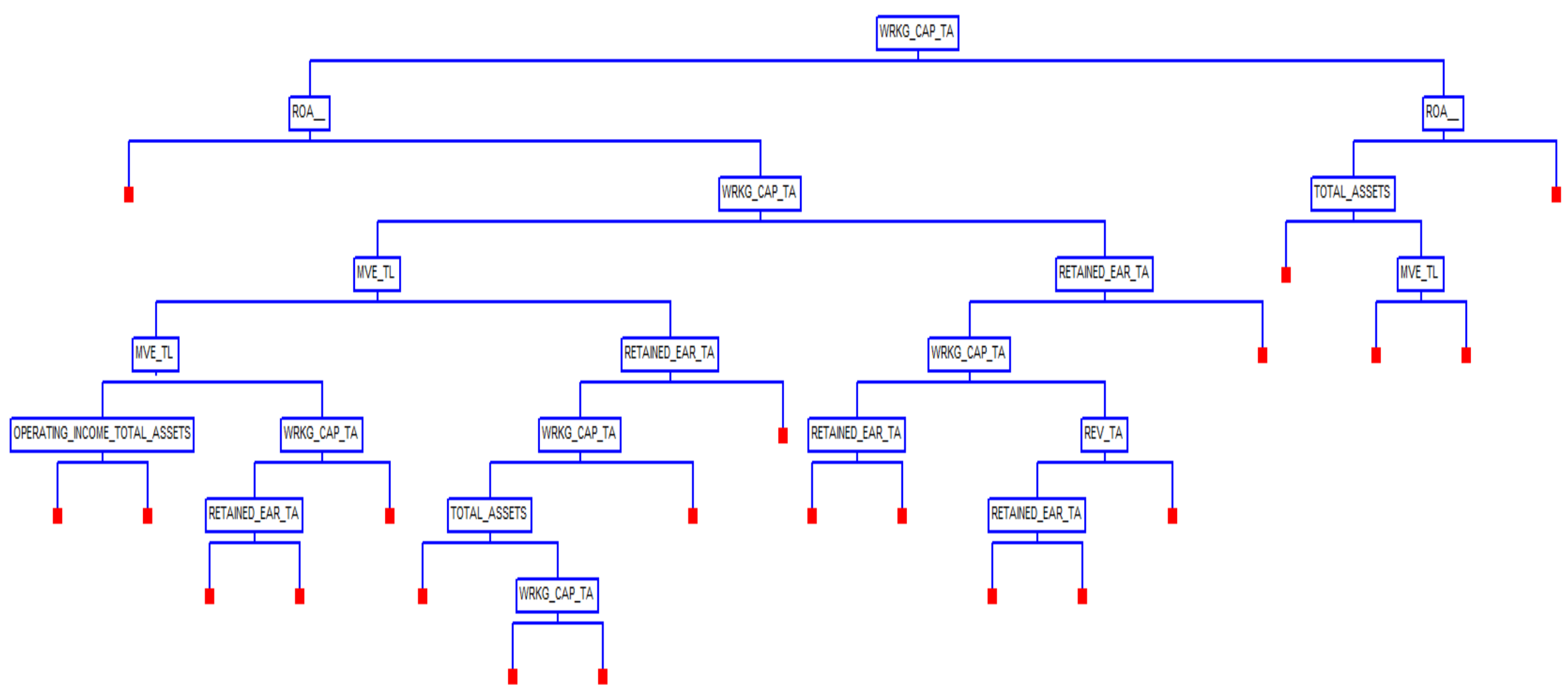

This author accepted manuscript is deposited under a Creative Commons Attribution Non-commercial 4.0 International (CC BY-NC) licence.

This means that anyone may distribute, adapt, and build upon the work for non-commercial purposes, subject to full attribution.

If you wish to use this manuscript for commercial purposes, please contact permissions@emerald.com. 


\section{Altman Z-Score for Service Firms Method}

Figure 6 provides an illustration of the single DT model for Altman's Z-Score for Service Firms Method. Again, 'Working Capital/Total Assets' shows up as the most important variable in FDP. RF and SGB models confirmed this as the most important variable. The second most important variable was Current Ratio for both DT and RF, whereas it appeared as the third most important using SGB. Refer to Table 3 for more information.

\section{Figure 6: Altman Z-Score for Service Firms Decision Tree}

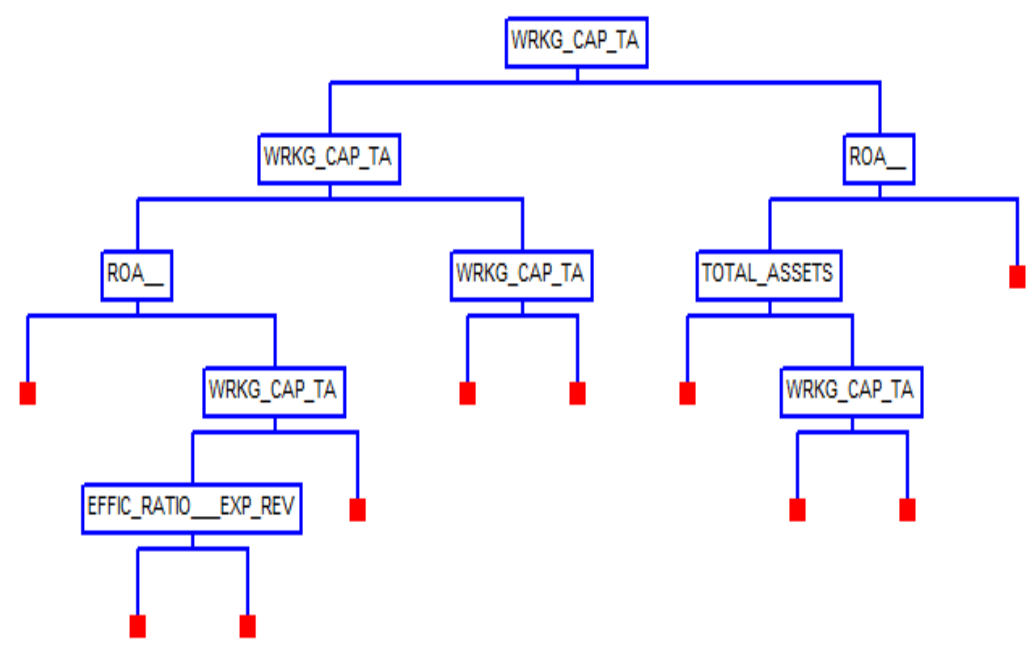

\section{Standardised Profits Method}

A decision tree with 'ROR' as the root node was developed for this method. See Figure 7 for illustration. 'ROR' is the most important variable in this model, but RF found Total Debt/Total Equity. SGB agreed with the single tree that ROR is the most important variable. Total Debt/Total Equity and Retained Earnings/Total Assets are clearly also important across all models. Refer to Table 3 for more detail.

\section{Figure 7: Standardised Profits Decision Tree}

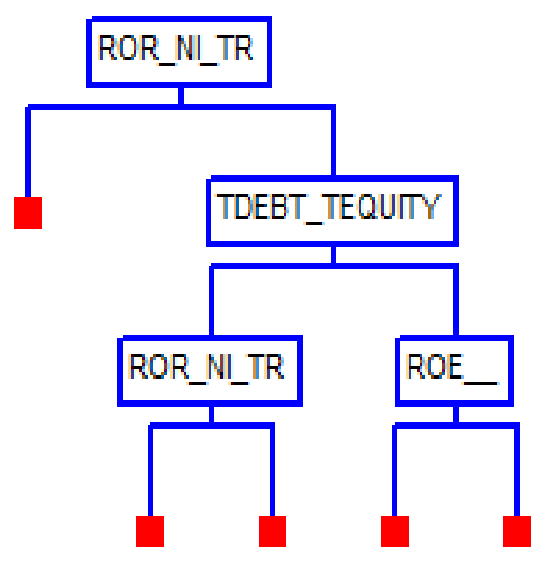


Table 3: Model comparison Table

\begin{tabular}{|c|c|c|}
\hline Method & Model & Most Significant Variables (in order of significance) \\
\hline \multirow{3}{*}{ Altman Z-Score } & $\begin{array}{c}\text { Decision Tree } \\
\text { (CART) }\end{array}$ & $\begin{array}{ll}\text { 1. } & \text { Working Capital/Total Assets } \\
\text { 2. } & \text { Current Ratio } \\
\text { 3. } & \text { Debt Ratio } \\
\text { 4. } & \text { Retained Earnings/Total Assets }\end{array}$ \\
\hline & $\begin{array}{c}\text { Random } \\
\text { Forest }\end{array}$ & $\begin{array}{l}\text { 1. Working Capital/Total Assets } \\
\text { 2. Current Ratio } \\
\text { 3. Total Assets } \\
\text { 4. Equity Ratio }\end{array}$ \\
\hline & $\begin{array}{l}\text { Stochastic } \\
\text { Gradient } \\
\text { Boosting } \\
\text { (TREENET) }\end{array}$ & $\begin{array}{l}\text { 1. Working Capital/Total Assets } \\
\text { 2. Debt Ratio } \\
\text { 3. Retained Earnings/Total Assets } \\
\text { 4. Market Value of Equity/Total Liabilities }\end{array}$ \\
\hline \multirow{3}{*}{$\begin{array}{l}\text { Altman Z-Score } \\
\text { for Service Firms }\end{array}$} & $\begin{array}{c}\text { Decision Tree } \\
\text { (CART) }\end{array}$ & $\begin{array}{l}\text { 1. Working Capital/Total Assets } \\
\text { 2. Current Ratio } \\
\text { 3. Debt Ratio } \\
\text { 4. Total Assets } \\
\end{array}$ \\
\hline & $\begin{array}{c}\text { Random } \\
\text { Forest }\end{array}$ & $\begin{array}{l}\text { 1. Working Capital/Total Assets } \\
\text { 2. Current Ratio } \\
\text { 3. Total Assets } \\
\text { 4. Equity Ratio }\end{array}$ \\
\hline & $\begin{array}{l}\text { Stochastic } \\
\text { Gradient } \\
\text { Boosting } \\
\text { (TREENET) } \\
\end{array}$ & $\begin{array}{l}\text { 1. Working Capital/Total Assets } \\
\text { 2. Debt Ratio } \\
\text { 3. Current Ratio } \\
\text { 4. Retained Earnings }\end{array}$ \\
\hline \multirow{3}{*}{$\begin{array}{l}\text { Standardised } \\
\text { Profits Method }\end{array}$} & $\begin{array}{c}\text { Decision Tree } \\
\text { (CART) }\end{array}$ & $\begin{array}{ll}\text { 1. } & \text { ROR } \\
\text { 2. } & \text { Total Debt/Total Equity } \\
\text { 3. } & \text { Market Value of Equity/Total Liabilities } \\
\text { 4. } & \text { Retained Earnings/Total Assets }\end{array}$ \\
\hline & $\begin{array}{c}\text { Random } \\
\text { Forest }\end{array}$ & $\begin{array}{l}\text { 1. Total Debt/Total Equity } \\
\text { 2. ROR } \\
\text { 3. Total Revenue/Total Assets } \\
\text { 4. } \text { Retained Earnings/Total Assets } \\
\end{array}$ \\
\hline & $\begin{array}{l}\text { Stochastic } \\
\text { Gradient } \\
\text { Boosting } \\
\text { (TREENET) }\end{array}$ & $\begin{array}{ll}\text { 1. } & \text { ROR } \\
\text { 2. } & \text { Retained Earnings/Total Assets } \\
\text { 3. } & \text { ROA } \\
\text { 4. } & \text { Market Value of Equity/Total Liabilities }\end{array}$ \\
\hline
\end{tabular}




\section{Discussion}

As shown in our results, there is a need for a specific measure of financial distress for Islamic banks, as there is a big difference between applying the old Altman standard and the new Beck (2013) approach. The results above showcase the similarities between the Altman (1968) Z-Score method and the Altman Z-Score for Service Firms method, as they have 'Working Capital/Total Assets' as the most predictive variable, and Current Ratio and Debt Ratio appear in second and third place using the different techniques/models. This similarity is unsurprising and helps the reliability of our results. It also shows how the Standardised Profits method differs from the first two methods, as it has 'ROR' (Return on Revenue) = Net Income/Total Revenue; as the most predictive variable, using DTs and SGB, and the second most predictive using RF. This may be due to the banks being service firms, the aforementioned ratios, which comprehensively deal with the capital/monetary aspects of the bank, are best indicators when forecasting for a bank's failure. This is in alignment with the Basel Accords, as explained below, as it recommends focusing on the capital risk of the banks.

By using lagged variables to predict the future state of Islamic banks, this gives rise to the potential of implementing proactive measurements by senior management to deviate the bank from the road to bankruptcy. It can also provide governmental watchdog institutions an alert to notify the bank of the impending dangers ahead should they perpetuate the status quo. Other stakeholders like investors also benefit as they can make informed decisions about whether to stay with the bank or go elsewhere due to a forecasted danger the following year.

As for regulatory implications, the Basel Accords play a key role in reforming the banks' operations. The Basel Accords are three sets of banking regulations (Basel I, II and III) set by the Basel Committee on Bank Supervision (BCBS). They provide recommendations on banking regulations in regard to capital risk, market risk, and operational risk. The function of the accords is to make sure that financial institutions have sufficient capital on hand to meet obligations and withstand unforeseen losses. Basel I was issued in 1988 and it focuses on the capital adequacy risk of financial institutions - international banks should have a risk weight of $8 \%$ or less. Basel II is an updated version of the original accord; it coined the 3 pillars: minimum capital requirements, supervisory review of an institution's capital adequacy and internal assessment process, and effective use of disclosure (Federal Reserve, 2003). Basel III was established in the wake of the GFC, it is a continuation of the three pillars, as well as extra requirements and safeguards (BIS, 2016). Even though, as Beck et al. (2013) found, Islamic banks are better capitalised, hence can withstand unforeseen losses better visà-vis conventional banks, by using lagged variables (identified in the previous section and in our predictive models) in conjunction with the Basel Accords, management can determine whether the company is in the 'danger zone' or whether their risk is marginal. This will enhance the longevity of banks in the marketplace. 


\section{Conclusion}

This paper has focused on cutting-edge financial distress prediction models and applied them to Islamic banks. These models can be used to forecast impending risks to enable the decision makers to take the preventive measures to hold-off such risks or mitigate their effect. Recursive partitioning techniques were employed to test for the most accurate method in predicting financial distress. Our results indicated that there is a need for a specific financial distress mechanism for Islamic banks, as variables that are indicative of a bank's status differ between the old Altman (1968) standard and novel approaches. 'Working Capital/Total Assets' was the most predictive variable for forecasting financial distress in Islamic banks using all 3 models used in this paper across both methods: Altman Z-Score and Altman ZScore for Service Firms. As for the Standardised Profits method, 'Return On Revenue' was the most influential variable. Therefore, our models should be used, as well as the aforementioned two variables, in conjunction with the recommendations made by the Basel Accords, when making decisions pertaining to FDP of Islamic banks.

\section{Acknowledgment}

The authors are grateful to the anonymous referees and the editor for their invaluable insight on the earlier version of the paper. Their comments helped shape our paper and add an extra dimension to our findings.

\section{References}

Altman, E. I. (1968). Financial Ratios Discriminant Analysis \& The Prediction of Corporate Bankruptcy. The Journal of Finance, 23(4), 589-609.

Altman, E. I. (1993). Corporate Financial Distress and Bankruptcy (2nd ed.). New York: John Wiley \& Sons.

Altman, E. I., Iwanicz-Drozdowska, M., Laitinen, E. K., \& Suvas, A. (2014). Distressed Firm and Bankruptcy Prediction in an International Context: A Review and Empirical Analysis of Altman's Z-Score Model. Retrieved from http://ssrn.com/abstract=2536340

Anderson, S. (2006). Investment management and mismanagement: history, findings, and analysis (Vol. 17). New York: Springer Science \& Business Media.

ASIC. (2015). Corporate insolvencies: September quarter 2015. Australia: Australian Securities \& Investments Commission. Retrieved from http://download.asic.gov.au/media/3446712/insolvency-statistics-summaryseptember-quarter-2015-published-10-november-2015.pdf

Beaver, W. H. (1966). Financial ratios as predictors of failure. Journal of accounting research, 71-111.

Beck, T., Demirguc-Kunt, A., \& Merrouche, O. (2013). Islamic vs. Conventional banking: Business model, efficiency and stability. Journal of Banking and Finance, 37, 433447. 
Berg, D. (2007). Bankruptcy prediction by generalized additive models. Applied Stochastic Models in Business and Industry, 23(2), 129-143.

BIS. (2016). Basel III: international regulatory framework for banks. Retrieved from Bank for International Settlements: http://www.bis.org/bcbs/basel3.htm

Breiman, L. (1984). Classification and Regression Trees. Boca Raton, Florida, USA, Florida , USA: CRC Press.

Chandra, K., Ravi, V., \& Bose, I. (2009). Failure prediction of dotcome companies using hybrid intelligent techniques. Expert systems with applications, 36(3), 4831-4837.

Chen, M.-Y. (2011). Predicting corporate financial distress based on integration of decision tree classification and logistic regression. Expert Systems with Applications, 38(9), 11261-11272.

Chung, K., Tan, S., \& Holdsworth, D. (2008). Insolvency Prediction Model Using Multivariate Discriminant Analysis and Artificial Neural Network for the Finance Industry in New Zealand. International Journal of Business and Management, 39(1), 19-28.

Ciampi, F., \& Gordini, N. (2013). Small enterprise default prediction modelling through artificial neural networks: An empirical analysis of Italian small enterprises. Journal of Small Business Management, 51(1), 23-45.

Coats, P. K., \& Fant, L. F. (1993). Recognizing financial distress patterns using a neural network tool. Financial Management, 22(3), 142-155.

Cybinski, P. (2001). Description, explanation, prediction - the evolution of bankruptcy studies. Managerial Finance, 27(4), 29-44.

Daniel, B.-O., \& Ionut, G. (2013). Prediction of corporate bankruptcy in Romania through the use of logistic regression. Annals of Faculty of Economics, 1(1), 976-986.

Dorsey, R., Edmister, R., \& Johnson, J. (1995). Bankruptcy prediction using artificial neural systems. The research of foundation of the institute of chartered financial analysts, 1995(3), 1-52.

EY. (2016). World Islamic Banking Competitiveness Report . EY. Retrieved from http://www.ey.com/Publication/vwLUAssets/ey-world-islamic-bankingcompetitiveness-report-2016/\$FILE/ey-world-islamic-banking-competitivenessreport-2016.pdf

Fantazzini, D., \& Figini, S. (2009). Random survival forests models for SME credit risk measurement. Methodology and Computing in Applied Probability, 11(1), 29-45.

Federal Reserve. (2003, June 18). Capital Standards for Banks: The Evolving Basel Accord. Retrieved from Federal Reserve: https://www.federalreserve.gov/pubs/bulletin/2003/0903lead.pdf

FitzPatrick, P. J. (1932). A Comparison of the Ratios of Successful Industrial Enterprises With Those of Failed Companies. The Certified Public Accountant, 598-605.

Frydman, H., Altman, E. I., \& KAO, D.-L. (1985). Introducing recursive partitioning for financial classification: the case of financial distress. The Journal of Finance, 40(1), 269-291.

Geng, R. B., Bose, I., \& Chen, X. (2015). Prediction of financial distress: An empirical study of listed Chinese companies using data mining. European Journal of Operational Research, 241(1), 236-247.

Gepp, A., \& Kumar, K. (2012). Business Failure Prediction Using Statistical Techniques: A Review. In K. Kumar, \& A. Chaturvedi, Some Recent Developments in Statistical Theory and Applications (pp. 1-25). Boca Raton: Brown Walker Press.

Gepp, A., Kumar, K., \& Bhattacharya, S. (2010). Business failure prediction using decision trees. Journal of forecasting, 29(6), 536-555. 
Hanif, M. (2011). Differences and Similarities in Islamic and Conventional Banking. International Journal of Business and Social Science, 2(2), 166-175.

Hertz, J., Krogh, A., \& Palmer, R. (1991). Introduction to the theorg of neural computing. New York: Addison Wesley.

Hua, Z., Wang, Y., Xu, X., Zhang, B., \& Liang, L. (2007). Predicting corporate financial distress based on integration of support vector machine and logistic regression. Expert Systems with Applications, 33(2), 434-440.

Huarng, K., Yu, H., \& Chen, C. (2005). The application of decision trees to forecast financial distressed companies. . Proceedings of International Conference on Intelligent Technologies and Applied Statistics. Taipei.

Hung, C., \& Chen, J.-H. (2009). A selective ensemble based on expected probabilities for bankruptcy prediction. Expert systems with applications, 36(3), 5297-5303.

Jaikengit, A. (2004). Corporate governance and financial distress : an empirical analysis the case of Thai financial institutions. USA: Case Western Reserve University.

Jan, A., \& Marimuthu, M. (2015). Altman Model and Bankruptcy Profile of Islamic Banking Industry: A Comparitive Analysis of Financial Performance. International Journal of Business and Management, 10(7), 110-119.

Kumar, P. R., \& Ravi, V. (2007). Bankruptcy prediction in banks and firms via statistical and intelligent techniques-A review. 180(1), 1-28.

Kyriazopoulos Georgios, M. (2014). The Edward I. Altman's Model of Bankruptcy and the implementation of it on the Greek cooperative banks. 9th Annual MIBES International Conference, (pp. 423-436).

Laitinen, E. K., \& Laitinen, T. (2001). Bankruptcy prediction: application of the Taylor's expansion in logistic regression. International review of financial analysis, 9(4), 327349.

Lee, S., \& Choi, W. (2013). A multi-industry bankruptcy prediction model using backpropagation neural network and multivariate discriminant analysis. Expert Systems with Applications, 40(8), 2941-2946.

Liau, Y.-S. (2017, January 6). Islamic Finance. Retrieved from Bloomberg: https://www.bloomberg.com/quicktake/islamic-finance

Mamo, A. (2011). Applicability of Altman (1968) model in predicting financial distress of commercial banks in Kenya. Phd Dissertation.

Mukkamala, S., Vieira, A., \& Sung, A. H. (2006). Model selection and feature ranking for financial distress classification. Proceedings of the 8th International Conference on Enterprise Information Systems (ICEIS 2006). INSTICC - Institute for Systems and Technologies of Information, Control and Communication. Retrieved from http://ww.rmltech.com/doclink/ICEIS\%202006\%20Submitted\%20for\%20Publication. pdf

Nanni, L., \& Lumini, A. (2009). An experimental comparison of ensemble of classifiers for bankruptcy prediction and credit scoring. Expert Systems with Applications, 36(2), 3028-3033.

Ohlson, J. (1980). Financial ratios and the proabilistic prediction of bankruptcy. Journal of Accounting Research (Spring), 109-131.

Perez, M. (2006). Artificial neural networks and bankruptcy forecasting: a state of the art. Neural Computer \& Application, 15(2), 154-163.

Phillips, C. H. (2012). S\&P Capital IQ. Journal of Business \& Finance Librarianship, 17(3), 279-286. doi:10.1080/08963568.2012.685022

Ravi, V., Kumar, P., Srinivas, E. R., \& Kasabov, N. K. (2007). A Semi-Online Training Algorithm for the Radial Basis Function Neural Networks: Applications to Bankruptcy. In V. Ravi, Advances in Banking Technology and Management: Impacts 
of ICT and CRM: Impacts of ICT and CRM (pp. 243-260). Information of Science Reference.

Sharma, N. (2013). Altman model and financial soundness of Indian banks. International Journal of Accounting and FInance, 1(3), 55-60.

Shultz, K. S., Hoffman, C. C., \& Reiter-Palmon, R. (2005). Using archival data for IO research: Advantages, pitfalls, sources, and examples. The Industrial-Organizational Psychologist, 42(3), 31-37.

Standard \& Poor's. (2014). Retrieved from Financial Times: http://www.ft.com/fastft/files/2014/10/13-Capture(2).PNG

Sun, J., \& Li, H. (2008). Data mining method for listed companies' financial distress prediction. Knowledge Based Systems, 21(1), 1-5.

Tan, C. (2001). Artificial Neural Networks: Applications in Financial Distress Prediction \& Foreign Exchange Trading (New ed). Gold Coast: Wilberto.

Yu, Q., Miche, Y., Severin, E., \& Lendasse, A. (2014). Bankruptcy prediction using extreme learning machine and financial expertise. Neurocomputing, 128, 296-302.

Zhang, H., \& Singer, B. (2010). Recursive Partitioning and Applications (2nd ed.). New York: Springer-Verlag. 